\title{
The Potential of Rat Inner Cell Mass and Fetal Neural Stem Cells to Generate Chimeras
}

\author{
GUO Ji-tong ${ }^{1,2}$, LI Xue-feng ${ }^{3}$, Shahnaz Fida ${ }^{1}$, GOU Ke-mian ${ }^{1}$, Nakisa Malakooti ${ }^{1}$, \\ ZHANG Chun-fang ${ }^{1}$, John R Morrison ${ }^{1}$, Alan O Trounson ${ }^{2}$, DU Zhong-tao ${ }^{1,4, *}$, \\ (1. CopyRat Pty Ltd, 27-31 Wright Street, Clayton, Victoria 3168, Australia; 2. Monash Immunology and Stem Cell Laboratories (MISCL), Monash \\ Science Technology Research and Innovation Precinct (STRIP), Building 75, Monash University, Wellington Road, Clayton, Victoria 3800, Australia; \\ 3. School of Life Science, South China Normal University, Guangzhou Guangdong 510631, P. R. China; 4. Monash Animal Service, Building 41, \\ Monash University, Wellington Road, Clayton, Victoria 3800, Australia)
}

\begin{abstract}
The rat chimera is an important animal model for the study of complex human diseases. In the present study we evaluated the chimeric potential of rat inner cell masses (ICMs) and fetal neural stem (FNS) cells. In result, three rat chimeras were produced by day 5 (D5) Sprague-Dawley (SD) blastocysts injected with ICMs derived from day 6 (D6) and D5 Dark Agouti (DA) blastocysts; four rat chimeras had been generated by D5 DA blastocyst injected with D5 SD ICMs. For the requirement of gene modification, cultured rat inner cell mass cells were assessed to produce chimeras, but no chimeras were generated from injected embryos. The potential to generate chimeras from rFNS and transfected rFNS cells were tested, but no chimeric pups were produced. Only 2 of 41 fetuses derived from D5 DA blastocyst injection with SD LacZ transfected rFNS cells showed very low number of LacZ positive cells in the section. These results indicate that $\mathrm{DA}$ and SD rat ICMs are able to contribute to chimeras, but their potential decreases significantly after culture in vitro $(P<0.05)$, and rFNS cells only have the potential to contribute to early fetal development.
\end{abstract}

Key words: Rat chimeras; Inner cell mass; Rat fetal neural stem cells; Blastocyst injection

\section{大鼠内细胞团和胎儿神经干细胞构建嵌合体的潜力}

郭继粀 ${ }^{1,2}$, 李雪峰 ${ }^{3}$, Shahnaz Fida ${ }^{1}$, 苟克勉 ${ }^{1}$, Nakisa Malakooti ${ }^{1}$, ZHANG Chun-fang ${ }^{1}$, John R Morrison $^{1}$, Alan O Trounson ${ }^{2}$, DU Zhong-tao ${ }^{1,4, *}$

(1. CopyRat Pty Ltd, Clayton, Victoria 3168, Australia; 2. Monash Immunology and Stem Cell Laboratories, Monash University,Clayton, Victoria 3800, Australia; 3. 华南师范大学 生命科学学院, 广东 广州 510631; 4. Monash Animal Service, Building 41, Monash University, Wellington Road, Clayton, Victoria 3800, Australia)

摘要：嵌合体大鼠是研究人类疾病的重要动物模型。用囊胚注射法研究了大鼠内细胞团 (ICM) 和胎儿神经 干细胞（FNS）构建嵌合体的潜力。结果发现来自黑色（DA）大鼠第 5 天（D5）和第 6 天（D6）囊胚的 ICM 细 胞注入 D5 Sprague-Dawley（SD）大鼠囊胚后得到 3 只嵌合体大鼠；D5 SD 大鼠 ICM 细胞注射入 D5 DA 囊胚后得 到 4 只嵌合体大鼠; 而体外培养的 DA 或 SD 大鼠 ICM 细胞注射后均未能获得嵌合体大鼠。本研究用大鼠胎儿神 经干细胞 (rFNS) 和 LacZ 转染的 rFNS 构建嵌合体, 未能获得嵌合体大鼠; 但在 LacZ 转染的 SD rFNS 注射到 $\mathrm{DA}$ 大鼠囊胚后发育来的 41 只胎儿中, 有 2 只胎儿其组织切片中发现少量 LacZ 阳性细胞。结果表明 DA 和 SD 大 鼠 ICM 具有参与嵌合体发育的潜力, 但 ICM 细胞经体外培养后构建嵌合体的潜力显著下降 $(P<0.05)$; 大鼠胎儿 神经干细胞构建嵌合体的潜力较低, 可能仅具有参与早期胚胎发育的潜力。

关键词：大鼠嵌合体；内细胞团；大鼠胎儿神经干细胞；囊胚注射

中图分类号: Q132.8 文献标识码: A 文章编号: 0254-5853-(2009)02-0158-07

Production of gene knockout mouse models by germline transmission chimeras derived from embryonic stem (ES) cells has become a useful research tool. DNA could be easily introduced into ES cells by a variety of

Received date: 2008-08-20; Accepted date: 2009-03-05

*Corresponding author (通讯作者), E-mail: zhongtao.du@adm.monash.edu.au

收稿日期：2008-08-20；接受日期：2009-03-05 
infection or transfection protocols and then delivered to offspring by production of germline chimeras (Tam \& Rossant, 2003). Thus, knockout mice can conventionally be created by aggregation of the ES cells with morulae or injection of the ES cells into blastocysts. Differentiation potential of the cells in developing embryos gradually decreases, but some of them still retain their self-renewal differentiation potential. Recent advances in stem cell research demonstrate that neural stem (NS) cells, which can be isolated from both the fetal and adult central nervous system (Johansson et al, 1999), are not only capable of differentiating into neurones, astrocytes and oligodendrocytes, but also have the potential to differentiate into non-neural progeny in vitro (Galli et al, 2000; Rietze et al, 2001). Some reports also showed that chimeric mice could be produced from adult hematopoietic stem cells (Geiger et al, 1998), as well as adult NS cells (Clarke et al, 2000). These results suggested that NS cells derived from neurospheres had self-renewal capacity and multipotency in the mouse. However, doubts have been raised about the pluripotency of NS cells recently. Greco et al (2004) reported that NS cells were unable to contribute to any chimeric animals, in fact, the cells rapidly differentiated into glia-like cells after injection into blastocysts. Because of these conflicting results, the potential of NS cells to generate chimeras needs to be investigated further.

The rat is often considered as a more physiologically relevant experimental model for human diseases, such as cardiovascular disease, neurological disease, diabetes, arthritis, and many behavioural disorders. In contrast to the mouse, however, the rat embryo manipulation technologies and genetic manipulation approaches have not been well developed yet. A limited number of reports have been published on chimeric rats (Iannaccone et al, 1994) and cloned rats (Zhou et al, 2003). While rat ES cells or ES-like cells have been reported, there have not been reports about generation of rat chimeras with these ES cells. The first rat chimera from ES cells was reported in 1994, but the chimera actually was rat-mouse interspecies chimera because the rat ES cells were accidentally contaminated with mouse ES cells (Iannaccone et al, 1994; Brenin et al, 1997). So far, rat chimeras have been generated by aggregation of rat 8-cell embryos or morulae (Weinberg et al, 1985; Clegg et al, 1991) and by injection of freshly isolated inner cell mass (ICM) cells of blastocysts into 8-cell embryos (Buehr et al. 2003). Except for these limited studies described above, there have not been reports about production of rat chimeras from blastocyst injection with ICM cells or ES cells. The protocols to produce rat germline chimeras are still need to be improved.

In the present study, we attempted to develop a method to create rat chimeras by blastocyst injection and to investigate the potential of chimeric development of rat ICM cells derived from in vivo blastocysts, as well as in vitro cultured inner cell mass (cICM) cells. The possibility of rat fetal neural stem cells (rFNS) to generate chimeras by blastocyst injection has also been evaluated.

\section{Materials and Methods}

\subsection{Media}

All chemicals were purchased from Sigma-Aldrich unless otherwise stated. The medium used for rat embryo culture was based on mR1ECM and rat embryo manipulation was carried out in Hepes- buffered $\mathrm{mR} 1 \mathrm{ECM}$ containing $20 \mathrm{mmol} / \mathrm{L}$ Hepes and $5 \mathrm{mmol} / \mathrm{L}$ $\mathrm{NaHCO}_{3}$ (HR1ECM).

\subsection{Animals}

Female Hooded Wistar (HW) rats were purchased from Adelaide University (Adelaide, Australia). Sprague-Dawley outbred (SD) and Dark Agouti inbred (DA) rats were purchased from Monash University (Melbourne, Australia). All rats were kept at a temperature of $22^{\circ} \mathrm{C}$ with light on at 08:00 am and off at 20:00 pm. All experiments were performed in accordance with the guidelines of Monash University Animal Experimentation Ethics Committee for care and use of laboratory animals.

\subsection{Isolation and culture of rat inner cell mass cells}

Immature 4-week-old female SD and DA rats were superovulated by subcutaneous injection of $10 \mathrm{IU}$ eCG (Intervet, Castle Hill, NSW) followed $48 \mathrm{~h}$ later by intraperitoneal injection of $10 \mathrm{IU}$ hCG (Intervet, Castle Hill, NSW). The rats were paired overnight with males of the same strain following hCG injection. On the following morning, the rats were examined for the presence of vaginal plugs and the day was taken as day 1 of pregnancy. Blastocysts were recovered by flushing of uteri in HR1ECM on day 5 of pregnancy (D5) or day 6 of pregnancy (D6). ICMs were isolated from the blastocysts by repeatedly pipetting with a fine pipette in $0.1 \%$ trypsin-EDTA within 2 mins. The small cell masses were selected, washed and incubated in HR1ECM till to injection. Some of the ICMs were cultured in mR1ECM supplemented with $10 \%$ fetal calf serum for 6 days and 
the cultured ICM cells (cICM) were mechanically isolated from the cultures before blastocyst injection.

\subsection{Isolation and culture of rat fetal neural stem cells}

Rat fetal neural stem cells (rFNS) were isolated from SD fetuses at day 12.5-14.5 of pregnancy in neurobasal-A culture medium (Gibco) with bFGF (10 $\mathrm{ng} / \mathrm{mL})$ and EGF $(10 \mathrm{ng} / \mathrm{mL})$. In brief, the fetal heads were isolated, minced and spun down. The pellet was resuspended in neurobasal-A media. The tissues were then further dissociated by pipetting until they were in homogeneous suspension. The cell suspension was plate onto fibronection plus polyL-Orithine precoated T75 flasks at a density of approximately $1.5 \times 10^{5}$ cells $/ \mathrm{mL}$ and cultured in humidified incubators at $37^{\circ} \mathrm{C}$ in $5 \%$ $\mathrm{CO}_{2}$ in air. Culture medium was replaced every other day. The cultures were passaged when neurospheres of undifferentiated cells formed. The rFNS cells at passage $1-5$ were trypsinized by $0.25 \%$ trypsin-EDTA and washed with HR1ECM before blastocyst injection.

\subsection{Transfection of rat fetal neural stem cells}

The LacZ vector containing $\beta$-galactosidase gene driven by human $\beta$-actin promoter was used to transfect rFNS cells. The purified plasmid DNA was resuspended in TE $(10 \mathrm{mmol} / \mathrm{L}$ Tris/HCl, $1 \mathrm{mmol} / \mathrm{L}$ EDTA, $\mathrm{pH} 8.0)$ buffer. The rFNS cells at passage 1-3 were scraped up when they were grown to $80 \%$ confluence. The cells were washed with phosphate-buffer saline (PBS, without $\mathrm{Ca}^{2+}$ and $\mathrm{Mg}^{2+}$ ) and resuspended in cold electroporation buffer (PBS with $\mathrm{Ca}^{2+}$ and $\mathrm{Mg}^{2+}$ ) at the concentration of $1 \times 10^{7}$ cells $/ \mathrm{mL}$. Ten micrograms of linear plasmid DNA was added into $0.4 \mathrm{~mL}$ of the cell suspension in electroporation cuvette. The cells were electroporated by using a Bio-Rad electroporation apparatus at $300 \mathrm{~V}$ and $400 \mu \mathrm{F}$ with a single electric pulse. Electroporated cells were transferred into $12 \mathrm{~mL}$ culture medium after 10 mins, and then reseeded into a 6 -well plate to culture at a $37^{\circ} \mathrm{C}$ humidified incubator with $5 \% \mathrm{CO}_{2}$ in air. After 48 $\mathrm{h}$ in culture, G418 was added to a final concentration of $50 \mu \mathrm{g} / \mathrm{mL}$ in neurobasal-A culture medium. The culture medium was changed every 3-5 days for selection of transgenic colonies. The individual colony was chosen to transfer into 24-well plates. The transfected cells were passaged when they were confluent. The rFNS-LacZ cells at passage 6-10 were trypsinized by $0.25 \%$ trypsin-EDTA and washed with HR1ECM before blatocyst injection.

\subsection{Injection of rat blastocyst}

Rat blastocysts used for injection recipients were collected in HR1ECM by flushing of uteri on day 5 of pregnancy (D5). Blastocyst injection was carried out at $28{ }^{\circ} \mathrm{C}$ under an inverted microscope. The injection pipette was cut and ground at a $45^{\circ}$ angle to an inner diameter of $20 \mu \mathrm{m}$ beforehand. About 1-2 ICMs, 6-10 cICM cells, or 5-10 rFNS cells were aspirated into the injection pipette and gently injected into the blastocoel cavity (Fig.1 A, B). The injected embryos were cultured in incubator for re-expansion of the blastocyst cavity, and then transferred into pseudo-pregnant HW rat recipients.

\subsection{Embryo transfer}

Embryo transfer recipients were prepared from matured HW female rats that were paired with vasectomized SD males overnight. On the following morning, vaginal plugs examined. The plugged rats were used as pseudo-pregnant recipients for embryo transfer, and the day was taken as day 1 of pregnancy. The recipients for embryo transfer were anesthetized by intraperitoneal injection of Avertin $(0.3 \mathrm{mg} / \mathrm{g}$ body weight $)$ at day 4 of pseudopregnancy. Ten to fifteen blastocysts were transferred into each side of the utero-tubal junction.

\subsection{Staining of LacZ for fetuses and newborn pup tissues}

The recipients were dissected at day 14 of pregnancy and fetuses (E14) were collected from the uteri. The fetuses were washed in $0.1 \mathrm{~mol} / \mathrm{L}$ phosphate buffer (PBS, $\mathrm{pH} 8.0)$ at room temperature and fixed in $0.2 \%$ glutaraldehyde $\left(5 \mathrm{mmol} / \mathrm{L}\right.$ EGTA, $2 \mathrm{mmol} / \mathrm{L} \mathrm{MgCl}_{2}$, $0.02 \% \mathrm{NP} 40,0.01 \%$ deoxycholate in PBS) at $4{ }^{\circ} \mathrm{C}$ for 16 $\mathrm{h}$. The fixed fetuses were then rinsed three times with washing buffer $\left(2 \mathrm{mmol} / \mathrm{L} \mathrm{MgCl}_{2}, 0.02 \% \mathrm{NP} 40,0.01 \%\right.$ deoxycholate in PBS) and stained overnight at $37^{\circ} \mathrm{C}$ with staining buffer $\left(5 \mathrm{mmol} / \mathrm{L}\right.$ EGTA, $2 \mathrm{mmol} / \mathrm{L} \mathrm{MgCl}_{2}$, $0.02 \% \mathrm{NP} 40,0.01 \%$ deoxycholate, $5 \mathrm{mmol} / \mathrm{L}$ potassium ferricyanide, $5 \mathrm{mmol} / \mathrm{L}$ potassium ferrocyanide) (Clarke et al, 2000). The stained fetuses were sectioned to check LacZ expression. Liver, testis or ovary, spleen, brain tissues from the newborn pups derived from the blastocysts injected with transfected rFNS cells were isolated and cut into $2-3 \mathrm{~mm}^{3}$ pieces to stain. The stained tissues were sectioned as the same as whole embryos.

\section{Results}

\subsection{Generation of rat chimeras with rat inner cell masses and cultured inner cell mass cells}

Twenty-one pups were born from 64 SD blastocysts injected with ICMs derived from DA blastocysts following embryo transfer into 3 recipients. Nine pups 
were born from 23 DA blastocysts injected with ICMs derived from SD blastocysts following embryo transfer. In total, seven pups are coat colour-patched chimeras. The chimeric efficiency of rat ICMs was about $8.0 \%$ (7/87) (Tab. 1).

Two litters of pups were born from two SD females mated with the coat colour-patched male chimera. Out of 20 pups, six pups showed agouti coat colour, which derived from DA, the others showed albino coat colour, which were derive from SD. The result showed that the coat colour-patched male was germline transmission chimera (Fig.1D). Following embryo transfer of $22 \mathrm{SD}$ blastocysts injected with D5 DA ICMs, two of seven pups showed coat colour-patches (Tab. 1, Fig.1C). The results indicated that rat ICMs derived from early blastocysts on day 5 and fully expended blastocysts on day 6 both had the potential to contribute to chimeras after blastocyst injection. In addition, nine pups were born from 23 DA blastocysts injected with D5 SD ICMs and four of them had coat colour-patches (Tab. 1, Fig. 1C). These results indicated that both SD and DA rat blastocysts can be used as recipients for blastocyst injection to produce rat chimeras.

However, no coat colour-patched rats were produced by injection of cICM cells derived from cultured ICMs. The chimeric efficiency of rat cICMs was very low $(0 \%, 7 / 87)$ (Tab. 2$)$.
Thus, the chimeric efficiency of rat ICMs was significantly higher than that of rat cICMs $(8.0 \%$ vs $0 \%$; $P<0.05, \chi^{2}$ test). The results suggested that rat ICMs freshly isolated from blastocysts had potential to develop into chimeras, but the chimeric potential of rat ICMs might be lost after culture in vitro for 6 days.

\subsection{Potential development of chimeras from blasto- cyst injection of rat fetal neural stem cells}

Twenty pups were born from 148 DA rat blastocysts injected with SD rFNS cells following embryo transfer into seven HW recipients. None of them was coat colour-patched (Tab. 3). Moreover, a total of 470 DA rat blastocysts were injected with LacZ transfected rFNS cells, and 88 pups were born following embryo transfer into $24 \mathrm{HW}$ recipients. In result, no coat colour-patched rat was observed from 20 of the pups; no LacZ positive section were obtained from the liver, testis, ovary, spleen or brain tissues of 68 newborn pups (Tab. 3). A total of 41 fetuses derived from 147 blastocysts injected with LacZ-transfected rFNS cells were collected from eight recipients at day 14 of gestation, and then were stained and sectioned. Two of them showed LacZ positive, but the staining was only found in very low cell numbers (Tab. 3, Fig. 1E, F). These results may suggest that the potential of rFNS cells can only contribute to early fetal development.

Tab. 1 Generation of rat chimeras from rat ICMs

\begin{tabular}{|c|c|c|c|c|c|}
\hline Donor ICMs & Recipient blastocysts & No. transferred & No. recipient & No. pups & No. chimeras \\
\hline D6 DA & $\mathrm{SD}$ & 42 & 2 & 14 & 1 \\
\hline D5 DA & SD & 22 & 1 & 7 & 2 \\
\hline D5 SD & DA & 23 & 1 & 9 & 4 \\
\hline \multicolumn{2}{|r|}{ Total } & 87 & 4 & 30 & $7(8.0 \%)$ \\
\hline
\end{tabular}

Tab. 2 Generation of rat chimeras from rat cICM cells

\begin{tabular}{cccccc}
\hline ICM cells & Recipient blastocysts & No. transferred & No. recipient & No. pups & No. chimeras \\
\hline DA & SD & 67 & 4 & $*$ & 0 \\
SD & DA & 26 & 1 & 3 & 0 \\
& Total & 93 & 5 & 3 & $0(0 \%)$ \\
\hline
\end{tabular}

*29 implantation scars were found at day 22 of pregnancy.

Tab. 3 Potential chimeric development from rFNS cells

\begin{tabular}{|c|c|c|c|c|c|}
\hline \multirow{2}{*}{ Donor cell } & \multirow{2}{*}{ No. transferred } & \multirow{2}{*}{ No. recipient } & \multicolumn{2}{|c|}{ No. } & \multirow{2}{*}{ No. chimeras } \\
\hline & & & pups & fetuses & \\
\hline rFNS & 148 & 7 & 20 & & 0 \\
\hline rFNS-LacZ & 470 & 24 & 88 & & $0^{\mathrm{a}}$ \\
\hline rFNS-LacZ & 147 & 8 & & $41^{\mathrm{b}}$ & $2^{\mathrm{c}}$ \\
\hline
\end{tabular}

${ }^{a}$ Tissues from 68 newborn pups were sectioned and examined; Coat colours were examined from 20 pups.

${ }^{\mathrm{b}}$ Fetuses were collected at day 14 of the gestation.

${ }^{\mathrm{c}} \mathrm{LacZ}$ staining was positive in the section of the fetus. 

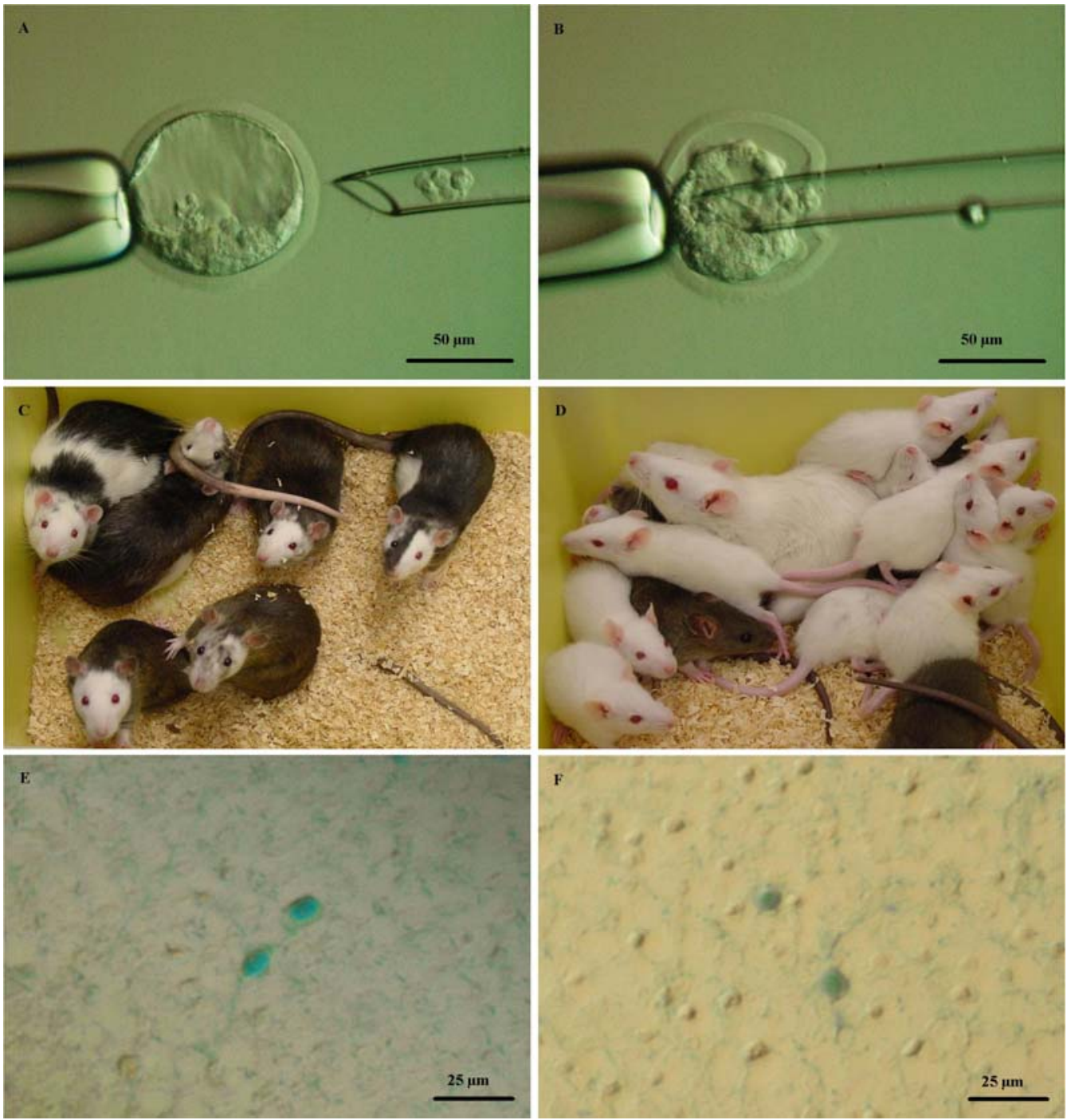

Fig. 1 Chimeric potential of rat inner cell mass (ICM) and fetal neural stem cells

(A) ICM was aspirated within the injection pipette; (B) The ICM was injected into day 5 (D5) blastocyst cavity; (C) Coat colour-patched chimeric rats from Day 5 (D5) SD (4 pups, 3-week old) and (D5) DA (2 pups, 4-week old) ICM exchange; (D) Pups from SD female rat mated with the coat colour-patched male chimera derived from SD blastocyst injected with DA ICMs. Coat colours of the pups were separated into the colour of DA ICM donor (agouti) and SD recipient blastocyst (albino); (E, F) LacZ positive cells were stained in two of the E14 whole embryo sections (original $\times 200$ ).

\section{Discussion}

Although it has been a standard protocol for producing mouse chimeras by blastocyst injection with ICMs, there has been no report about producing rat chimeras by blastocyst injection. So far, there have only been reports demonstrating the production of rat chimeras by aggregation of 8-cell embryos or morulae (Weinberg et al, 1985; Clegg et al, 1991), or by 8-cell embryos injected with ICMs (Buehr et al, 2003). Here we have generated rat chimeras by SD or DA ICM exchange injection between SD and DA rat strains. This demonstrated that DA inbred and SD outbred rats could both be used as recipient blastocysts to produce chimeras, and rat ICMs derived from day 6 blastocysts still retain the ability to form chimeras after being reintroduced into recipient embryos. The rat ICM cells are very sensitive, longer exposure to trypsin will result in culture failure for stem cell-like cell isolation (data not shown). Here we showed that it did not effect on generating of chimeras by short time exposure to low concentration of trypsin combined with mechanical pipetting for isolation of the ICMs from day 5 or day 6 expanded blastocysts. Attempts were also made to create rat chimeras by injection of cultured ICM cells in this study; however, no chimeras were produced by blastocyst injection with 
such cultured ICM cells from neither DA nor SD rat blastocysts. It suggests that ICM cells may have lost the potential to contribute to chimeras following culture in mR1ECM containing fetal calf serum. These results supported the earlier report, in which Ouhibi et al (1995) indicated that rat ICM cells differentiated rapidly after 3-6 days in primary culture even when they were cultured on fibroblast feeder layers. Potential of cultured ICM cells decrease rapidly due to the loss of POU-domain transcription factor Oct-4 expression following culture in vitro, because expression of Oct-4 is essential for cells to maintain their pluripotency (Buehr et al, 2003). Rat chimera had not been gengerated in this study, it might be the same reason, but it still needs to be investigated. These results suggest that rat ICM cells are very different from mouse ICM cells because germline chimeric mice can be efficiently produced by mouse ES cells that were even cultured in the medium with synthetic serum and in the absence of a feeder layer for a long period time (Buehr et al, 2003). To Maintain the potential of rat ICM cells in vitro for gene modification therefore remains a challenge.

Mouse NS cells can be isolated and long-term culture techniques are available without losing multipotency so far. Those cells can then be used for generating chimeras by aggregation with morulae or by injection into blastocysts (Clarke et al, 2000). They also can be reprogrammed to develop into cloned offspring by nuclear transfer (Kawase et al, 2000). Mouse blastocyst is the good microenvironment not only for mouse ES cells or murine hematopoietic stem cells to chimerically redevelop into fetal and adult tissues (Geiger et al, 1998) but also for human hematopoietic stem cells (Harder et al, 2002) and human acute myeloid leukaemia cells (Harder et al, 2003) to redevelop. In the report, murine NS cells contributed to chimeric fetal liver, yolk sac and peripheral blood, but chimeric cells only were detected in adult neural tissues (Harder et al, 2004). Rat NS cells have previously been isolated, and could be cultured for a long-term period in vitro (Svendsen et al, 1997). This improvement gives us enough time to modify rat NS cell genome for purpose, but these cells have not been used to produce chimeras yet. In the present study, we produced chimeric fetuses with rat FNS cell line we established, while we have failed to produce an adult chimera with the cells. The results show that rat FNS cells can restrictively contribute to fetal chimeric tissues, but the potential of the rat FNS cells was limited. Greco et al (2004) raised doubts about the pluripotency of NS cells because detection rate of mouse NS cells were decreased rapidly after injection into blastocysts during the first $96 \mathrm{~h}$ and no chimerism was detected in any organs of E13.5-15.5 fetuses. One explanation for the result is that cell fusion happened between donor and recipient cells during embryo growth. Spontaneous cell fusion has been widely observed in NS cells and bone marrow cells when they were cultured in vitro or following transplantation in vivo (Wang et al, 2003; Willenbring et al, 2004). Thus, chimeric fetuses and adult tissues produced by blastocyst injection with hematopoietic stem cells, acute myeloid leukaemia cells, and neural stem cells could be caused by cell fusion between donor and recipient cells (Geiger et al, 1998; Durr et al, 2003). Our observation of positive staining for donor FNS cells was detected in chimeric fetuses but not in the tissues of newborn pups. Therefore, formation of hybrid cells may occur in our experiments, but it still remains to be investigated further. The pluripotency of NS cell is not as the same as the ES cells after being injected into blastocysts.

Trophectoderm cells are the first cells to appear during differentiation in the mouse, it is impossible to produce chimeras with trophectoderm cells by either aggregation or injection method (Sotomaru et al, 1997). However, chimeras can be produced from the ICM cells derived from trophectoderm cell nuclear transfer, and the ES cell lines also can be established by nuclear transfer of mouse fetal neural cells (Kawase et al, 2000). This result indicates that mouse somatic cells can be dedifferentiated by nuclear transfer and can redevelop to chimeras. Rat cloning is very difficult because rat oocytes are spontaneously activated after ovulation. So far, only one paper reported that rat has been successfully cloned (Zhou et al, 2003). Replacing rat oocyte by mouse oocyte, an attempt of iSCNT was carried out by injection of rat FNS cell into mouse or bovine enucleated oocyte. Although the blastocysts derived from mouse oocyte iSCNT were obtained, but it was failed to generate rat chimeras with the ICMs. Unfortunately, only 8-cell embryos were developed from bovine oocyte iSCNT (data not shown). Isolation of the rat ES cell-like cells from mouse oocyte iSCNT derived-ICM was also failed (data not shown). The results suggest that rat embryo early development is very sensitive to lots of factors compared with mouse. How to maintain rat ICM cells undifferentiated, as well as understanding of rat embryo development remains to be investigated. 
Acknowledgments: We would like to thank Dr Ed Stanley for providing the $L a c Z$ vector and we are grateful to Dr. Nancy Ruduck for critical review of the manuscript.

\section{References:}

Brenin D, Look J, Hubner N, Levan G, Iannaccone P. 1997. Correction: Pluripotent embryonic stem cells from the rat are capable of producing chimeras[J]. Dev Biol, 185: 124-125.

Buehr M, Nichols J, Stenhouse F, Mountford P, Greenhalgh CJ, Kantachuvesiri S, Brooker G, Mullins J, Smith AG. 2003. Rapid loss of Oct-4 and pluripotency in cultured rodent blastocysts and derivative cell lines[J]. Biol Reprod, 68: 222-229.

Clarke DL, Johansson CB, Wilbertz J, Veress B, Nilsson E, Karlstrom H, Lendahl U, Frisen J. 2000. Generalized potential of adult neural stem cells[J]. Science, 288: 1660-1663.

Clegg KB, Sambhi MP. 1991. Chimeric rats from the fusion of genetically hypertensive and normotensive rat embryos[J]. Clin Exp Hypertens A, 13: 955-961.

Durr M, Harder F, Merkel A, Bug G, Henschler R, Muller AM. 2003. Chimaerism and erythroid marker expression after microinjection of human acute myeloid leukaemia cells into murine blastocysts[J]. Oncogene, 22: 9185-9191.

Galli R, Borello U, Gritti A, Minasi MG, Bjornson C, Coletta M, Mora M, De Angelis MG, Fiocco R, Cossu G, Vescovi AL. 2000. Skeletal myogenic potential of human and mouse neural stem cells[J]. Nat Neurosci, 3: 986-991.

Geiger H, Sick S, Bonifer C, Muller AM. 1998. Globin gene expression is reprogrammed in chimeras generated by injecting adult hematopoietic stem cells into mouse blastocysts[J]. Cell, 93: 1055-1065.

Greco B, Low HP, Johnson EC, Salmonsen RA, Gallant J, Jones SN, Ross AH, Recht LD. 2004. Differentiation prevents assessment of neural stem cell pluripotency after blastocyst injection[J]. Stem Cells, 22: 600-608.

Harder F, Henschler R, Junghahn I, Lamers MC, Muller AM. 2002. Human hematopoiesis in murine embryos after injecting human cord blood-derived hematopoietic stem cells into murine blastocysts[J]. Blood, 99: 719-721.

Harder F, Kirchhof N, Petrovic S, Wiese S, Muller AM. 2004. Erythroid-like cells from neural stem cells injected into blastocysts[J]. Exp Hematol, 32: 673-682.

Iannaccone PM, Taborn GU, Garton RL, Caplice MD, Brenin DR. 1994. Pluripotent embryonic stem cells from the rat are capable of producing chimeras[J]. Dev Biol, 163: 288-292.

Johansson CB, Momma S, Clarke DL, Risling M, Lendahl U, Frisen J. 1999. Identification of a neural stem cell in the adult mammalian central nervous system[J]. Cell, 96: 25-34.

Kawase E, Yamazaki Y, Yagi T, Yanagimachi R, Pedersen RA. 2000. Mouse embryonic stem (ES) cell lines established from neuronal cell-derived cloned blastocysts[J]. Genesis, 28: 156-163.

Ouhibi N, Sullivan NF, English J, Colledge WH, Evans MJ, Clarke NJ. 1995. Initial culture behaviour of rat blastocysts on selected feeder cell lines[J]. Mol Reprod Dev, 40: 311-324.

Rietze RL, Valcanis H, Brooker GF, Thomas T, Voss AK, Bartlett PF. 2001. Purification of a pluripotent neural stem cell from the adult mouse brain[J]. Nature, 412: 736-739.

Sotomaru Y, Kato Y, Tsunoda Y. 1997. A comparative investigation on the potency of cells from the inner cell mass and trophectoderm of mouse blastocysts to produce chimeras $[\mathrm{J}]$. Theriogenology, $\mathbf{4 8}$ : 977-984.

Svendsen CN, Skepper J, Rosser AE, ter Borg MG, Tyres P, Ryken T. 1997. Restricted growth potential of rat neural precursors as compared to mouse[J]. Brain Res Dev Brain Res, 99: 253-258.

Tam PP, Rossant J. 2003. Mouse embryonic chimeras: tools for studying mammalian development[J]. Development, 130: 6155-6163.

Wang X, Willenbring H, Akkari Y, Torimaru Y, Foster M, Al-Dhalimy M, Lagasse E, Finegold M, Olson S, Grompe M. 2003. Cell fusion is the principal source of bone-marrow-derived hepatocytes $[\mathrm{J}]$. Nature, 422: 897-901.

Weinberg WC, Howard JC, Iannaccone PM. 1985. Histological demonstration of mosaicism in a series of chimeric rats produced between congenic strains[J]. Science, 227: 524-527.

Willenbring H, Bailey AS, Foster M, Akkari Y, Dorrell C, Olson S, Finegold M, Fleming WH, Grompe M. 2004. Myelomonocytic cells are sufficient for therapeutic cell fusion in liver[J]. Nat Med, 10: 744-748.

Zhou Q, Renard JP, Le Friec G, Brochard V, Beaujean N, Cherifi Y, Fraichard A, Cozzi J. 2003. Generation of fertile cloned rats by regulating oocyte activation[J]. Science, 302: 1179. 